\title{
Hip Resurfacing After Screws for Femoral Neck Fracture - A Bold Decision with 8 Years of Follow-Up
}

\author{
Hugo Miguel Moreira Aleixo* \\ Department: Orthopedic Surgery Department, Hip Unit, Hospital Pedro Hispano, Portugal
}

Submission: June 26, 2017; Published: July 05, 2017

*Corresponding author: Hugo Miguel Moreira Aleixo, Department: Orthopedic Surgery Department, Hip Unit, Hospital Pedro Hispano, Hospital address: Rua Dr. Eduardo Torres, Postal code: 4460 Senhora da Hora, Portugal, Tel: +351916464430, Email: humimoal@hotmail.com

\begin{abstract}
Introduction: Hip resurfacing (HR) is a well-known alternative for hip arthroplasty for end-stage hip osteoarthritis (OA) in younger patients. Although there's still some controversy in the use of metal-on-metal implants, HR is a viable option in terms of range of motion (ROM) and overall survivorship, although technically more demanding. Indications are becoming more restricted to young active male with big femoral heads. We present a single case report of a hip resurfacing prosthesis implanted after a femoral neck fracture treated previously, which could be considered a borderline indication. A 64 years old male, who had been operated with 3 cannulated screws for a femoral neck fracture due to a traumatic fall, started developing ipsilateral OA. The Hip Unit at our Institution decided to implant a HR (Wright - Conserve Plus ®).
\end{abstract}

Methods: We present a single case report of a HR prosthesis implanted after a femoral neck fracture treated previously, with 95 month of follow-up. We reviewed the radiographs and clinical records done in that time period. There was a presential interview with the patient and registered its physical exam. We did new radiographs and answered to the UCLA, Harris Hip Score and Oxford Hip Score. We analysed the positioning of the prosthesis by an AP X-ray and measured the cervico-diaphyseal angle and acetabular position as well and registered sign and symptoms of aseptic loosening, like inflammatory osteolysis and periarticular bone loss.

Results: In the clinical records, there is reference to the patient's satisfaction with the implant and progressive increasing of ROM. About the physical exam, the ROM was $100^{\circ}$ flexion, $10^{\circ}$ extension, $40^{\circ}$ abduction and adduction $20^{\circ}$, without any pain. Radiographically, there was no subsidence of the implant in this period of time. The cervico-diaphyseal angle was $43^{\circ}$ and the acetabular index was $37^{\circ}$ and it maintained the same. The patient responded the questionnaires with a UCLA score of 9, HHS 37 and OHS 97. There are no signs of aseptic loosening.

Discussion: HR shows again it is a good option for painful young hips in active patients. Although this can be considered a borderline indication for a HR implantation, the clinical and radiographical results are good/excellent. We consider that even in these cases, hip resurfacing showed its place at our Institution arsenal. The results show us that HR must be considered as an option.

Keywords: Resurfacing; Arthroplasty; Femoral neck fracture; Young adult

\section{Introduction}

Hip osteoarthritis $(\mathrm{OA})$ is a well-known condition that can appear at any age Oliveria SA [1]. It consists of a degenerative process where continued cartilage breakdown results from mechanical overload, causing secondary bony and synovial changes and characteristic clinical and radiographic findings $[2,3]$. Evidence is accumulating that primary hip $\mathrm{OA}$ is actually secondary to a subtle mechanical problems like mild dysplasia [4,5] or femoroacetabular impingement (FAI) [6-8]. Osteoarthritis can be managed with conservative measures, like physical therapy and pain relief but most of the times it will advance to a more degenerative hip, leading to progressive loss of range of motion (ROM) and pain, along with decreasing levels of quality of life [9]. This can be quite important when we are talking about young patients that reject any type of joint pain, seek early advice and want solutions that allow them to maintain the previous level of activity. When a surgical option is required, it is of the utmost importance the type of prosthesis offered to the patient, especially in the young population [10]. The current options vary from a standard stem hip prosthesis, a short stem with big femoral heads or a HR [11].

\section{Choosing HR in a special case}

The best reported results for HR are young males $(<60$ years old), active patients with good bone stock and a diagnosis of osteoarthritis [12]. Since the 1990s, metal-on-metal (MoM) HRA has achieved excellent outcomes when used in the appropriate patient population. Concerns regarding the metal-on-metal bearing surface including allergy and adverse local tissue reaction (ALTR) to metal debris have recently lead to a decline 
in the use of this construct. There is some controversy and no final evidence has been produced. Some authors state a direct relationship between large femoral metal-on-metal heads and increased tissue reaction, pseudotumor formation, metal patch test-reactivity and atopic dermatitis $[13,14]$. However, at the same time, other authors found no real association between these factors $[15,16]$.

Indications for hip resurfacing are more restricted nowadays, due to the proof of time that transformed initial indications into contra-indications now [17]. The advantages are obvious: bone stock preservation, easy return to impact sport, low dislocation rate with increased ROM and easier revision surgery, if needed [18-20]. However, this comes with disadvantages of early implant failure with specific designs, femoral neck fracture, adverse local tissue reaction (ALTR) to metal debris and systemic increase in metal ions the need for an extended surgical exposure, and increased technical demands for implantation [21].

\section{Methods}

We present a single case report of a 68 years old patient with a HR prosthesis implanted after a femoral neck fracture treated previously, with 95 month of follow-up. We reviewed the radiographs and clinical records done in that time period. There was a presential interview with the patient and registered its physical exam. We did new radiographs and answered to the UCLA, Harris Hip Score and Oxford Hip Score. We analysed the positioning of the prosthesis by an AP X-ray and measured the cervico-diaphyseal angle and acetabular position as well and registered sign and symptoms of aseptic loosening, like inflammatory osteolysis and periarticular bone loss.

\section{Results}

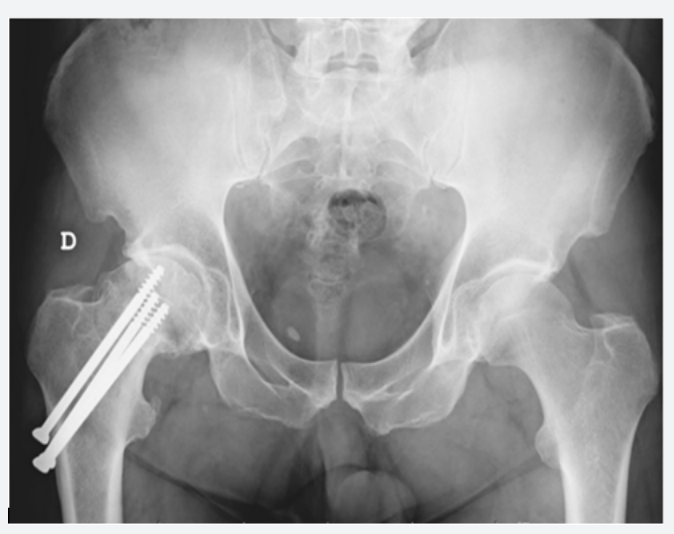

Figure 1: Femoral neck Osteosynthesis with 3 cannulated screws.

This patient was a highly active 60 years old male that had a traumatic femoral neck fracture. The option was three cannulated parallel screws and the fracture healed at 6 weeks, without any residual pain (Figure 1). There is no register to cartilage damage during this surgery. However, the patient started developing a symptomatic osteoarthritis. Later on, two years after this surgery, osteoarthritis developed and surgery was the option. The patient had all the indications for a hip resurfacing, except the former neck fracture. This would theoretically increase the risk for post-operative femoral neck fracture and revision arthroplasty. After discussing the options, as well as its advantages and disadvantages, the patient accepted and was operated. The surgeon is a Conserve Plus $₫$ prosthesis user (Wright Medical) and it was implanted by a modified antero-lateral Hardinge approach (Figure 2).

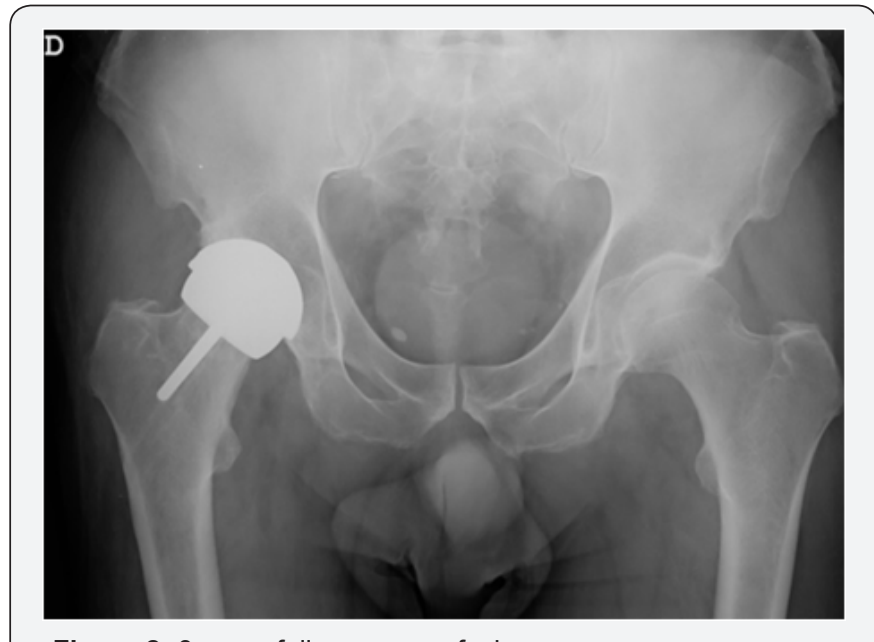

Figure 2: 8 years follow up resurfacing.

In the clinical records, there is reference to the patient's satisfaction with the implant and progressive increasing of ROM. About the physical exam, the ROM was $100^{\circ}$ flexion, $10 \cong$ extension, $40^{\circ}$ abduction and adduction $20^{\circ}$, without any pain. Radiographically, there was no subsidence of the implant in this period of time. The cervico-diaphyseal angle was $43^{\circ}$ and the acetabular index was $37^{\circ}$ and it maintained the same. The patient responded the questionnaires with a UCLA score of 9, HHS 37 and OHS 97. There are no signs of aseptic loosening.

\section{Discussion}

Although this can be considered a borderline indication for a HR implantation, the clinical and radiographical outcomes show us excellent results at 8 years follow-up. We consider that even in these cases with potential failure, choice must be done according to the surgeon's own experience, as the rate of complication are higher in badly positioned implants. Close clinical follow-up and patient surveillance is necessary to quickly identify and address implant failures. For this reasons, hip resurfacing showed its place at our Institution arsenal. The results show us that this must be considered as an option.

\section{References}

1. Oliveria SA, Reed JI, Cirillo PA, Walker AM (1995) Incidence of symptomatic hand, hip, and knee osteoarthritis among patients in a health maintenance organization. Arthritis Rheum 38(8): 1134-1141. 
2. Jordan D, Yuging Zhang D (2010) Epidemiology of Osteoarthritis. Clin Geriartr Med (26): 355-369.

3. Harris W (1986) Etiology of osteoarthritis of the hip. Clin Orthop Relat Res 213: 20-33.

4. Hartofilakidis (2016) Lessons learned from study of congenital hip disease in adults. World J Orthop. 7: 785-792.

5. Mansour (2016) The management of residual acetabular dysplasia: updates and controversies. J Pediatr Orthop B. 26(4): 344-349.

6. Zhang C (2015) Femoroacetabular impingement and osteoarthritis of the hip. Can Fam Physician 61(12): 1055-1060.

7. Ganz R (2003) Femoroacetabular impingement: a cause for osteoarthritis of the hip. Clin Orthop Relat Res 417: 112-120.

8. Siebenrock K (2015) Twelve percent of hips with a primary cam deformity exhibit a slip-like morphology resembling sequelae of slipped capital femoral epiphysis. Clin Orthop Relat Res 473(4): 12121223.

9. Murphy N (2016) Hip Osteoarthritis: Etiopathogenesis and Implications for Management. Adv Ther 33(11): 1921-1946.

10. Smet D (2009) Hip resurfacing: expectations and limitations. Acta Orthop 80(5): 625-626.

11. Silverman E (2016) Metal-on-metal total hip arthroplasty: is there still a role in 2016? Curr Rev Musculoskelet Med 9(1): 93-96.

12. Ribas M (2014) Hip resurfacing arthroplasty: mid-term results in 486 cases and current indication in our institution. Hip Int 24(19-24).
13. Campbell P (2010) Histological features of pseudotumor-like tissues from metal-on-metal hips. Clin Orthop Relat Res 468(9): 2321-2327.

14. Brewster D (2013) Risk of cancer following primary total hip replacement or primary resurfacing arthroplasty of the hip: a retrospective cohort study in Scotland. Br J Cancer 108(9): 1883-1890.

15. Hjorth M (2016) No association between pseudotumors, high serum metal-ion levels and metal hypersensitivity in large-head metal-onmetal total hip arthroplasty at 5-7-year follow-up. Skeletal Radiol 45(1): 115-125.

16. Gustafson K (2014) Metal release and metal allergy after total hip replacement with resurfacing versus conventional hybrid prosthesis. Acta Orthop 85(4): 348-354.

17. Sershon R (2016) Current indications for hip resurfacing arthroplasty in 2016. Curr Rev Musculoskelet Med 9(1): 84-92.

18. Krantz N (2012) Hip resurfacing in patients under thirty years old: an attractive option for young and active patients. Int Orthop 36(9): 17891794.

19. Corten K (2011) Hip resurfacing arthroplasty: current status and future perspectives. Eur Cell Mater 21: 243-258.

20. Cadossi M (2015) Hip Resurfacing Implants. Orthopedics 38(8): 504 509.

21. Gerhardt G (2015) Changes in bone mineral density and femoral neck narrowing in the proximal femur three to five years after hip resurfacing versus conventional total hip arthroplasty. J Arthroplasty 20(2): 308-314.

\section{Your next submission with Juniper Publishers will reach you the below assets}

- Quality Editorial service

- Swift Peer Review

- Reprints availability

- E-prints Service

- Manuscript Podcast for convenient understanding

- Global attainment for your research

- Manuscript accessibility in different formats

( Pdf, E-pub, Full Text, Audio)

- Unceasing customer service

Track the below URL for one-step submission https://juniperpublishers.com/online-submission.php 